\title{
Soil test crop response based Integrated plant nutrition system for desired yield target of preseasonal sugarcane ratoon on Inceptisols
}

\author{
N. B. Ghube' ${ }^{1}$ A. D. Kadlag² and B. M. Kamble ${ }^{3 *}$ \\ ${ }^{\mathbf{1}}$ Department of Soil Science and Agriculture Chemistry, College of Agriculture, Naigaon (Bz)-431709 \\ (Maharashtra), INDIA \\ ${ }^{2}$ Department of Soil Science and Agricultural Chemistry, Mahatma Phule Krishi Vidyapeeth, Rahuri-413722 \\ (Maharashtra), INDIA \\ ${ }^{3}$ Agricultural Research Station, Kasabe Digraj, Sangli- 416305 (Maharashtra), INDIA \\ *Corresponding author. E-mail:bmkamble2007@rediffmail.com \\ Received: October 3, 2016; Revised received: January 22, 2017; Accepted: April 23, 2017
}

\begin{abstract}
Studies on Soil Test Crop Response based Integrated Plant Nutrition System (STCR - IPNS) were conducted adopting the Inductive cum Targeted yield model on Inceptisols (Vertic Haplustepts) in Rahuri, District Ahemadnagar, Maharashtra, India in order to develop fertilizer prescriptions through IPNS for the desired yield targets of preseasonal sugarcane ratoon. The field experiments were carried out with maize as gradient crop for plant cane and after harvest of plant cane, pre-seasonal sugarcane ratoon as test crop. Using the data on yield, initial soil test values on available nitrogen $(\mathrm{N})$, phosphorus $(\mathrm{P})$, potassium $(\mathrm{K})$, doses of fertilizers and farmyard manure (FYM) applied and NPK uptake, the basic parameters viz., nutrient requirement, contribution from soil, fertilizers and FYM were computed. It was found that $1.56 \mathrm{~kg} \mathrm{~N}, 0.58 \mathrm{~kg} \mathrm{P}$ and $1.04 \mathrm{~kg} \mathrm{~K}$ were required for producing one tonne millable cane of preseasonal ratoon sugarcane. The per cent contributions of $\mathrm{N}, \mathrm{P}$ and $\mathrm{K}$ from soil and FYM for preseasonal sugarcane ratoon were $37.65,85.88$ and 19.82 per cent and $11.83,10.88$ and 12.24 per cent, respectively. Making use of these basic parameters, fertilizer prescription equations were developed for pre-seasonal sugarcane ratoon (var. C0-94012) and an estimate of fertilizer doses formulated for a range of soil test values and desired yield targets under NPK alone and IPNS (NPK plus FYM)
\end{abstract}

Keywords: Basic parameter, Fertilizer prescription equation, Soil test crop response, Sugarcane, Targeted yield

\section{INTRODUCTION}

Fertilizer application is one of the efficient means of increasing agricultural profitability. The fertilizer prices have gone up and hence, their use in required amounts depends much upon the purchasing ability of the farmers. At the same time a balanced fertilization has to be considered for maintaining soil health for sustainable use because indiscriminate and imbalanced use of fertilizers has already distorted soil fertility and deteriorated soil health in India (Santhi et al., 2011). Sugarcane being a long duration, exhaustive crop removes considerably higher amount of plant nutrients from the soil. On an average, sugarcane crop, yielding 100 tonnes, removes 208, 53 and $280 \mathrm{~kg}$ per hectare of $\mathrm{N}, \mathrm{P}_{2} \mathrm{O}_{5}$ and $\mathrm{K}_{2} \mathrm{O}$, respectively from the soil. The major factors responsible for declining of Sugarcane productivity in Maharashtra are imbalance use of fertilizers and poor irrigation management. Thus, scientific control in the application of fertilizers certainly needed to improve sugarcane yield. The fertilizer recommendation based on soil test crop response (STCR) is more quantitative, precise and meaningful because combined use of soil and plant analysis is involved in it. It gives a real balance between applied nutrients and the available nutrients already present in the soil. Soil test based application of plant nutrient helps to realize higher response ratio and benefit: cost ratio as the nutrients are applied in proportion to the magnitude of the deficiency of a particular nutrient and the correction of the nutrients imbalance in soil helps to harness the synergistic effects of balanced fertilization. Fertilizer application based on targeted yield approach was found beneficial in increasing yield (Ramamoorthy et al., 1967; Bhandari et al., 2002; Ladha et al., 2003; Manna et al., 2005). Excessive and indiscriminate use of inorganic fertilizers creates imbalance of nutrition causing decline in productivity and simultaneously increased cost of production per tonne of cane. Application of adequate inorganic fertilizers supplemented with organic manures and biofertilizers on soil test basis will certainly be helpful for increasing productivity of sugarcane with better soil health. (Patil et al.,1994 and Jadhav et al., 2002). The soil test crop response on garlic in medium black calcareous soils of Saurashtra region of Gujarat, Sakarvadia et al. (2012) found yield targeting approach effective in soil fertility build up. Khosa et al. (2012) also reported the superiority of the 
target yield concept for rice -wheat over other practices as it gave higher yields and optimal economic returns.

In the present context of globalization and liberalization of Indian economy, the productivity of crops should be enhanced with little more cost. With increasing cost of fertilizers and reduced subsidies tends to give scope of development of alternative sources of nutrients. So far there is only general blanket recommendation of fertilizer application without considering soil fertility. The sugarcane crop is being grown in different soils and agro-climatic conditions with different varieties, so as to elucidate the significant relationship between soil test values and crop response to fertilizers and develop fertilizer prescription equations under IPNS for desired $120 \mathrm{MT} \mathrm{ha}^{-1}$ yield target of sugarcane ratoon.

\section{MATERIALS AND METHODS}

Studies on Soil Test Crop Response based Integrated Plant Nutrition System (STCR - IPNS) were conducted adopting the Inductive cum Targeted yield model, on a Vertic Haplustepts of Maharashtra, India. This study comprised of two field experiments in two phases viz., fertility gradient experiment with fodder maize (Phase I) and test crop experiment with preseasonal sugarcane ratoon C0-94012 (Phase II). The details of the field experiments carried out and methods of analysis of soil and plant samples and the methodology followed in the development of prescription equations are presented below.

The standard field experiment was conducted on preseasonal sugarcane (ratoon) at Mahatma Phule Krishi Vidyapeeth, Rahuri, Maharashtra, India using a fertility gradient approach. The experimental location was between $19^{\circ} 48^{\prime} \mathrm{N}$ and $19^{\circ} 57^{\prime} \mathrm{N}$ latitude and $74^{\circ} 19^{\prime}$ E longitude. In the gradient experiment, operational range of variation in soil fertility was created deliberately. For this purpose, the experimental field was divided into three equal strips, the first strip received no fertilizer $\left(\mathrm{N}_{0} \mathrm{P}_{0} \mathrm{~K}_{0}\right)$, the second and third strips received one $\left(\mathrm{N}_{1} \mathrm{P}_{1} \mathrm{~K}_{1}\right)$ and two $\left(\mathrm{N}_{2} \mathrm{P}_{2} \mathrm{~K}_{2}\right)$ times the standard dose of $\mathrm{N}, \mathrm{P}_{2} \mathrm{O}_{5}$ and $\mathrm{K}_{2} \mathrm{O}$, respectively and a gradient crop of fodder maize was grown. The variation in fertility gradient in different fertility gradient were observed from the soil test values in three fertility gradients. These fertility gradients were used for derivation of fertilizer prescription equation for plant preseasonal sugarcane ratoon. After harvest of plant preseasonal sugarcane the similar fertility gradient (strip) were used for conduct of soil test crop response correlation studies to develop fertilizer prescription equation for preseasonal ratoon sugarcane. Variation in fertility gradient was assessed treatment wise with strip by testing soil available NPK at harvest of plant preseasonal sugarcane. These soil test value assessed gradients (strips) are used as fertility gradient for conduct of preseasonal ratoon sugarcane. In fertility gradient experiment, the soil analysis data after harvest of plant preseasonal sugarcane showed that fertility gradients were created in the $F_{0}, F_{1}$ and $F_{2}$ strips. The yield of plant preseasonal sugarcane and soil fertility. The data on soil test values for available nitrogen, phosphorus and potassium at harvest of plant preseasonal sugarcane. These soil test values are used as fertility gradient for preseasonal ratoon sugarcane. After confirming the establishment of fertility gradients in the experimental field, in the second phase of the field experiment, three FYM blocks were created across the fertility gradient by applying three levels $\left(\mathrm{F}_{0} 0, \mathrm{~F}_{1} 15\right.$ and $\mathrm{F}_{2}$ $30 \mathrm{t} \mathrm{ha}^{-1}$ ) of FYM. Three FYM blocks were created across the fertility gradient. The experiment was laid out in a fractional factorial design comprising twenty four equal plots with varying $21 \mathrm{~N}, \mathrm{P}_{2} \mathrm{O}_{5}$ and $\mathrm{K}_{2} \mathrm{O}$ treatments along with 3 control treatments on randomized basis. The different combinations of various levels of $\mathrm{N}\left(150,250\right.$ and $\left.350 \mathrm{~kg} \mathrm{ha}^{-1}\right), \mathrm{P}_{2} \mathrm{O}_{5}(65,115$ and 165 $\left.\mathrm{kg} \mathrm{ha}^{-1}\right)$ and $\mathrm{K}_{2} \mathrm{O}\left(65,115\right.$ and $\left.165 \mathrm{~kg} \mathrm{ha}^{-1}\right)$ were randomly distributed in $\mathrm{F}_{0}, \mathrm{~F}_{1}$ and $\mathrm{F}_{2}$ strip. The twenty one treatments consisted asN $\mathrm{N}_{0}: \mathrm{P}_{115}: \mathrm{K}_{115}, \mathrm{~N}_{150}: \mathrm{P}_{65}: \mathrm{K}_{65}$, $\mathrm{N}_{150}: \mathrm{P}_{65}: \mathrm{K}_{115}, \mathrm{~N}_{150}: \mathrm{P}_{115}: \mathrm{K}_{65}, \mathrm{~N}_{150}: \mathrm{P}_{115}: \mathrm{K}_{115}, \mathrm{~N}_{250}$ : $\mathrm{P}_{0}: \mathrm{K}_{115}, \mathrm{~N}_{250}: \mathrm{P}_{65}: \mathrm{K}_{65}, \mathrm{~N}_{250}: \mathrm{P}_{65}: \mathrm{K}_{115}, \mathrm{~N}_{250}: \mathrm{P}_{115}$ : $\mathrm{K}_{65}, \mathrm{~N}_{250}: \mathrm{P}_{115}: \mathrm{K}_{0}, \mathrm{~N}_{250}: \mathrm{P}_{115}: \mathrm{K}_{115}, \mathrm{~N}_{250}: \mathrm{P}_{115}: \mathrm{K}_{165}$, $\mathrm{N}_{250}: \mathrm{P}_{165}: \mathrm{K}_{115}, \mathrm{~N}_{250}: \mathrm{P}_{165}: \mathrm{K}_{165}, \mathrm{~N}_{250}: \mathrm{P}_{65}: \mathrm{K}_{65}, \mathrm{~N}_{350}$ : $\mathrm{P}_{115}: \mathrm{K}_{165}, \mathrm{~N}_{350}: \mathrm{P}_{115}: \mathrm{K}_{115}, \mathrm{~N}_{350}: \mathrm{P}_{115}: \mathrm{K}_{165}, \mathrm{~N}_{350}$ : $\mathrm{P}_{165}: \mathrm{K}_{65}, \mathrm{~N}_{350}: \mathrm{P}_{165}: \mathrm{K}_{115}, \mathrm{~N}_{350}: \mathrm{P}_{165}: \mathrm{K}_{165}$. The N, P and $\mathrm{K}$ were applied through urea, single super phosphate and muriate of potash respectively as per treatments. Preseasonal sugarcane (CO-94012) was taken as a main test crop in these FYM blocks and after harvest of preseasonal sugarcane crop, the cane and top yield were recorded. Without disturbing the fertility gradient and FYM blocks, after harvest of preseasonal plant cane in February, 2008. The same field of harvested plant preseasonal sugarcane are used for soil test crop response correlation studies for preseasonal ratoon sugarcane to develop the relationship between soil test value and cane yields by conducting experiment on fertility gradient approach (Ramamoorthy et al., 1967) with view to derive fertilizer prescription equation for preseasonal ratoon sugarcane by conjoint use of chemical fertilizers and organic manures for making judicious and balanced fertilizer recommendations for a system as a whole. The treatment of $\mathrm{N}, \mathrm{P}_{2} \mathrm{O}_{5}$ and $\mathrm{K}_{2} \mathrm{O}$ proportions for preseasonal ratoon sugarcane were superimposed on the similar treatment of $\mathrm{N}, \mathrm{P}_{2} \mathrm{O}_{5}$ and $\mathrm{K}_{2} \mathrm{O}$ proportion of preseasonal plant sugarcane. At higher nutrient level imposed for plant cane were used for imposing the higher levels of nutrient for ratoon cane.

The soil sample were collected from a depth of 0-15 $\mathrm{cm}$ before the application of fertilizer and after harvest of both gradient and test crop. The soil samples were dried in shade ground and sieved $2 \mathrm{~mm}$ sieve for 
general analysis. The soil samples were analysed for available $\mathrm{N}$ by the alkaline permanganate method (Subbiah and Asija, 1956), available P (Olsen- P) by $0.5 \mathrm{M} \mathrm{NaHCO}_{3}$ extraction (Olsen et al., 1954), available $\mathrm{K}\left(\mathrm{NH}_{4} \mathrm{OAc}\right)$ by $1 \mathrm{~N}$ neutral $\mathrm{NH}_{4} \mathrm{OAc}$ extraction on flame photometer (Hanway and Heidal, 1952). The plant and grain samples were collected from both gradient and test crop and analyzed for total $\mathrm{N}$ by microKjeldahl method in $\mathrm{H}_{2} \mathrm{SO}_{4}: \mathrm{H}_{2} \mathrm{O}_{2} \quad(1: 1)$ digestion (Jackson, 1973), total $\mathrm{P}$ by vanadomolybdate yellow colour method in nitric acid $\mathrm{H}_{2} \mathrm{SO}_{4}: \mathrm{HClO}_{4}$ : $\mathrm{HNO}_{3}$ (1:4:10) digestion (Jackson, 1973) and total $\mathrm{K}$ on flame photometer in $\mathrm{H}_{2} \mathrm{SO}_{4}: \mathrm{HClO}_{4}: \mathrm{HNO}_{3}(1: 4: 10)$ (Chapman and Pratt, 1961) and their uptake values were computed.

From the soil test values, crop yield and uptake data, the basic parameter viz., nutrient requirement (NR), contribution from soil (CS), contribution from fertilizer (CF) and contribution from FYM (CFYM) were calculated as per the procedure given by Ramamoorthy et al., (1967). The basic parameters were used for derivation of fertilizer prescription equation with and without FYM for preseasonal sugarcane (ratoon). Based on the equation fertilizer recommendations were prescribed in the form of ready reckoner for desired yield target of 120 and $140 \mathrm{t} \mathrm{ha}^{-1}$ of preseasonal sugarcane (ratoon). The experimental data were analyzing by following the procedure given by Panse and Sukhatme (1985).

\section{RESULTS AND DISCUSSION}

Study site and soil description: The average annual precipitation during experiment period was $520 \mathrm{~mm}$. Out of the total annual rainfall, about 80 per cent rains are received from South-West monsoon (June to September) while rest receives from North-East monsoon. The number of rainy days were varies from 15 45 days in a year. Total rainfall received during the period from February, 2008 to January, 2009 was $670.7 \mathrm{~mm}$ in 23 rainy days. The experimental soil belongs to order Inceptisol and sub group of Vertic Haplustepts. The texture of the soil was clayey with low in available $\mathrm{N}\left(178.33 \mathrm{~kg} \mathrm{ha}^{-1}\right)$, medium in available $\mathrm{P}\left(18.78 \mathrm{~kg} \mathrm{ha}^{-1}\right)$ and very high in $\mathrm{K}(350.33 \mathrm{~kg}$ ha $\left.{ }^{1}\right)$. The soil was slightly alkaline in reaction with calcium carbonate content of 7.90 per cent.

Basic parameter: In the targeted yield model, The basic parameters for developing fertilizer prescription equations for preseasonal sugarcane ratoon are (i) nutrient requirement (NR) in $\mathrm{kg}$ per tonne of ratoon cane yield, per cent contribution of available NPK from soil (CS), fertilizers (CF) and farmyard manure (CFYM). Making use of data on the ratoon cane yield of sugarcane, total uptake of $\mathrm{N}, \mathrm{P}$ and $\mathrm{K}$, initial soil test values for available $\mathrm{N}, \mathrm{P}$ and $\mathrm{K}$ and doses of fertilizer $\mathrm{N}, \mathrm{P}_{2} \mathrm{O}_{5}$ and $\mathrm{K}_{2} \mathrm{O}$ applied, the basic parameters were computed. The basic data for fertilizer require- ment for targeted yield of preseasonal sugarcane ratoon are furnished in Table 1 . The average nutrient requirement of preseasonal sugarcane ratoon was found to be $1.56,0.58$ and $1.64 \mathrm{~kg} \mathrm{t}^{-1}$ of $\mathrm{N}, \mathrm{P}_{2} \mathrm{O}_{5}$ and $\mathrm{K}_{2} \mathrm{O}$ respectively. Similarly Katharine et al.,(2013) also reported that the nutrient requirement to produce one quintal $(100 \mathrm{~kg})$ of seed cotton was $4.43 \mathrm{~kg}$ of $\mathrm{N}$, $2.20 \mathrm{~kg}$ of $\mathrm{P}_{2} \mathrm{O}_{5}$ and $4.83 \mathrm{~kg}$ of $\mathrm{K}_{2} \mathrm{O}$. The percent contribution of nutrients from soil and fertilizers were found to be 37.65 and 34.83 for N, 85.88 and 36.99 for $\mathrm{P}_{2} \mathrm{O}_{5}$ and 19.82 and 30.80 for $\mathrm{K}_{2} \mathrm{O}$. Similarly the percent contribution of $\mathrm{N}, \mathrm{P}_{2} \mathrm{O}_{5}$ and $\mathrm{K}_{2} \mathrm{O}$ from FYM was $11.83,10.88$ and 12.24 respectively. The more contribution of $\mathrm{P}_{2} \mathrm{O}_{5}$ from soil as compare to $\mathrm{N}$ and $\mathrm{K}_{2} \mathrm{O}$.

Fertility gradient: The soil analysis data after harvest of plant preseasonal sugarcane showed that fertility gradients were created in the $\mathrm{F}_{0}, \mathrm{~F}_{1}$ and $\mathrm{F}_{2}$ strips (Table 2 ). The fertility gradient was developed due to addition of NPK fertilizers increasing from $F_{0}$ to $F_{2}$ strips, because in $\mathrm{F}_{2}$ gradient strip, the double dose of fertilizer was given against the recommended dose of fertilizer in $F_{1}$ strip, while in $F_{0}$ there was no application of fertilizers and hence, the fertility was built up from $F_{0}$ to $F_{2}$ as the fertilizer doses increased. The results clearly indicated that the development of soil fertility gradients in respect of NPK. Bangar (1991) reported the possibility of development of fertility gradients in respect of NPK with organic manure (FYM) as well as inorganic fertilizers and their combination in Sorghum var. CSH 8R.

Ratoon sugarcane yield, Uptake and available NPK status: The yield of plant preseasonal sugarcane were ranged between 114-165 $\mathrm{t} \mathrm{ha}^{-1}$ in $\mathrm{F}_{0}, 115-168 \mathrm{t} \mathrm{ha}^{-1}$ in $\mathrm{F}_{1}$ and 118-175 $\mathrm{t} \mathrm{ha}^{-1}$ in $\mathrm{F}_{2}$, respectively. The cane yield was increased to the tune of 1.43, 3.53 and 5.01 per cent in $F_{0}, F_{1}$ and $F_{2}$ gradient respectively (Table 2 ). It indicated that the response of fertilizer were higher side in low fertility gradient plots as compared to high fertility gradient. The fertilizer responses were about 1.05 times lower in low fertility gradient plots. The uptake of nutrient by plant preseasonal sugarcane were ranged between 92.25-282, 15-95.50 and 175$405 \mathrm{~kg} \mathrm{ha}^{-1}$ in $\mathrm{F}_{0}, 113-290,25-111.95$ and $255-375 \mathrm{~kg}$ $\mathrm{ha}^{-1}$ in $\mathrm{F}_{1}$ and 135-291, 31-117.05 and 291-465 kg hain $\mathrm{F}_{2}$ - for NPK, respectively. These results showed that there was slight increase in cane yield with an increased in NPK fertilizer application in low fertility gradient as compared to high fertility gradient. This might be associated with addition of FYM in each block, which might buffered native soil fertility by different gradients. Therefore, the cane yield level in different gradients was narrow. However, at low fertility gradient responses were higher to ratoon cane yields. Soil, fertilizers and FYM are the sources of supply of plant nutrients to the sugarcane. Therefore, the effect of these three sources of plant nutrients in sugarcane ratoon was interlinked with each other. The 
response to applied nutrients to crop was dependent on number of factors, among them fertility status of soil was one of the most important factor. Similar findings have also reported by Karem et al., (2012) the inorganic fertilizer application based on targeted yield along with organic manure (FYM) i.e. Integrated Plant $\mathrm{Nu}-$ trient System (IPNS) approach, that consisted of application of $98 \mathrm{~N}: 103 \mathrm{P}_{2} \mathrm{O}_{5}: 27 \mathrm{~K}_{2} \mathrm{O} \mathrm{kg} \mathrm{ha}{ }^{-1}$ through chemical fertilizers $+46 \mathrm{~N}: 36 \mathrm{P}_{2} \mathrm{O}_{5}: 45 \mathrm{~K}_{2} \mathrm{O} \mathrm{kg} \mathrm{ha}{ }^{-1}$ through $5 \mathrm{t} \mathrm{FYM} \mathrm{ha}^{-1}$ as organic manure, resulted in higher grain yield $4.04 \mathrm{tha}^{-1}$ of rice.

Fertilizer prescription equations for preseasonal ratoon sugarcane: The basic data on preseasonal ratoon sugarcane by using chemical fertilizers with and without FYM (Table 1) were transformed with the help of NR $\left(\mathrm{kg} \mathrm{t}^{-1}\right), \mathrm{CS}(\%), \mathrm{CF}(\%)$ and CFYM (\%) coefficients into workable fertilizer adjustment equations for different yield targets based on soil test values and are given below.

$\begin{array}{ll}\text { Without FYM } & \text { With FYM } \\ \mathrm{FN}=4.47 \mathrm{~T}-1.08 \mathrm{SN} & \mathrm{FN}=3.89 \mathrm{~T}-0.94 \mathrm{SN}-0.94 \\ & \mathrm{FYM} \\ \mathrm{FP}_{2} \mathrm{O}_{5}=1.56 \mathrm{~T}-2.32 \mathrm{SP} & \mathrm{FP}_{2} \mathrm{O}_{5}=1.12 \mathrm{~T}-1.66 \mathrm{SP}- \\ & 0.40 \mathrm{FYM} \\ \mathrm{FK}_{2} \mathrm{O}=3.37 \mathrm{~T}-0.64 \mathrm{SK} & \mathrm{FK}_{2} \mathrm{O}=3.06 \mathrm{~T}-0.58 \mathrm{SK}- \\ & 1.04 \mathrm{FYM}\end{array}$

Where $\mathrm{FN}, \mathrm{FP}_{2} \mathrm{O}_{5}$ and $\mathrm{FK}_{2} \mathrm{O}$ are fertilizer $\mathrm{N}, \mathrm{P}_{2} \mathrm{O}_{5}$ and $\mathrm{K}_{2} \mathrm{O}$ in $\mathrm{kg} \mathrm{ha}^{-1}$, T is yield target $\mathrm{tha}^{-1}$ and $\mathrm{SN}$, SP and SK are soil available $\mathrm{N}, \mathrm{P}$ and $\mathrm{K} \mathrm{kg} \mathrm{ha}^{-1}$ and FYM is

Table 1. Basic data from preseasonal sugarcane ratoon.

\begin{tabular}{lccc}
\hline Parameter & $\mathbf{N}$ & $\mathbf{P}$ & $\mathbf{K}$ \\
\hline NR $\left(\mathrm{kg} \mathrm{t}^{-1}\right)$ & 1.56 & 0.58 & 1.04 \\
\hline Without FYM & & & \\
\hline CS (\%) & 37.65 & 85.88 & 19.82 \\
CF (\%) & 34.83 & 36.99 & 30.80 \\
\hline With FYM & & & \\
\hline CF (\%) & 40.07 & 51.72 & 33.98 \\
CFYM (\%) & 11.83 & 10.88 & 12.24 \\
\hline
\end{tabular}

NR-nutrient requirement, CS- contribution from soil, CFcontribution from fertilizer, CFYM- contribution from farm yard Manure farm yard manure in $\mathrm{tha}^{-1}$.

Fertilizer response is denoted by the functional relationship between increase in crop yield and added fertilizers. It can be expressed graphically or algebraically by an equation. Vajantha et al., (2014) reported that the application of fertilizers based on STCR equation for target yield of $120 \mathrm{t} \mathrm{ha}^{-1}$ recorded highest cane yield $\left(121.5,117.8,114.2 \mathrm{t} \mathrm{ha}^{-1}\right.$ in plant crop I, plant crop II, ratoon, respectively). However, the STCR equation for targeted yield of $100 \mathrm{t} \mathrm{ha}^{-1}$ in sugarcane could be achieved without any negative deviation in Chittoor district soils. The yield targets were achieved within reasonable limits when the fertilizer was applied on soil test basis in majority of the crops thus establishing the utility of the prescription equations for recommending soil test based fertilizer application to the farmers. With this background, in the present investigation, soil test based fertilizer prescription equations for desired yield target of ratoon sugarcane was developed using the basic parameters obtained. The data clearly revealed the fact that the fertilizer $\mathrm{N}$, $\mathrm{P}_{2} \mathrm{O}_{5}$ and $\mathrm{K}_{2} \mathrm{O}$ requirements decreased with increase in soil test values and increased with increase in yield targets. Similar finding also reported in cotton by Katharine et al. (2013).

Fertilizer prescription under IPNS for desired yield target of ratoon sugarcane: The ready reckoners were prepared for fertilizer $\mathrm{N}, \mathrm{P}_{2} \mathrm{O}_{5}$ and $\mathrm{K}_{2} \mathrm{O}$ requirements in Table 3, 4 and 5, respectively for sole use of chemical fertilizers and for conjoint use of manure and chemical fertilizers, respectively. Soil test based fertilizer prescription equation for targeted yield of preseasonal sugarcane ratoon were formulated using the basic parameters and are furnished in Table 1 on the basis of these equation a ready reckoner was prepared for a range of soil test values and for yield targets of 100 , 120 and $140 \mathrm{t} \mathrm{ha}^{-1}$ under different fertilizers programmes (Table 3, 4 and 5). It was evident from the data that the fertilizer $\mathrm{N}, \mathrm{P}_{2} \mathrm{O}_{5}$ and $\mathrm{K}_{2} \mathrm{O}$ requirements decreased with increase in soil test values. For producing yield $120 \mathrm{t} \mathrm{ha}^{-1}$ of preseasonal sugarcane (ratoon)

Table 2. Range and average yields of preseasonal ratoon sugarcane, soil test values and total uptake of nutrients in different FYM blocks.

\begin{tabular}{|c|c|c|c|c|}
\hline Particulars & & $F_{0-} 0$ t FYM ha ${ }^{-1}$ & $F_{1}-15$ t FYM ha ${ }^{-1}$ & $F_{2}-30$ t FYM ha $^{-1}$ \\
\hline Sugarcane yield & Range & $114-165$ & $115-168$ & $118-175$ \\
\hline$\left(\mathrm{t} \mathrm{ha}^{-1}\right)$ & Average & 139.5 & 141.5 & 146.5 \\
\hline Soil available N & Range & $151-175$ & $175-233$ & $168-210$ \\
\hline$\left(\mathrm{kg} \mathrm{ha}^{-1}\right)$ & Average & 164.97 & 191.56 & 189.95 \\
\hline Soil available & Range & $12.11-18.50$ & $13.5-24.5$ & $10.0-21.0$ \\
\hline $\mathrm{P}\left(\mathrm{kg} \mathrm{ha}^{-1}\right)$ & Average & 14.17 & 16.79 & 15.76 \\
\hline Soil available & Range & $321-364$ & $301-375$ & $348-450$ \\
\hline $\mathrm{K}\left(\mathrm{kg} \mathrm{ha}^{-1}\right)$ & Average & 352.16 & 324.61 & 380.92 \\
\hline $\mathrm{N}$ uptake & Range & $92.25-282$ & $113-290$ & $135-291$ \\
\hline$\left(\mathrm{kg} \mathrm{ha}^{-1}\right)$ & Average & 187.00 & 201.50 & 213.00 \\
\hline P uptake & Range & $15-95.50$ & $25-111.95$ & $31-117.05$ \\
\hline$\left(\mathrm{kg} \mathrm{ha}^{-1}\right)$ & Average & 55.25 & 68.47 & 74.02 \\
\hline $\mathrm{K}$ uptake & Range & $175-405$ & $255-375$ & $291-465$ \\
\hline$\left(\mathrm{kg} \mathrm{ha}^{-1}\right)$ & Average & 290.00 & 315.00 & 378.00 \\
\hline
\end{tabular}


N. B. Ghube et al. / J. Appl. \& Nat. Sci. 9 (2): 799 - 804 (2017)

Table 3. Ready reckoners of nitrogen requirement for different yield target of preseasonal sugarcane ratoon.

\begin{tabular}{|c|c|c|c|c|c|c|}
\hline \multirow{3}{*}{$\begin{array}{l}\text { Soil available } \\
\mathrm{N}\left(\mathrm{kg} \mathrm{ha}^{-1}\right)\end{array}$} & \multicolumn{6}{|c|}{ Yield target $\left(\mathrm{t} \mathrm{ha}^{-1}\right)$} \\
\hline & \multicolumn{3}{|c|}{ Without FYM } & \multicolumn{3}{|c|}{ With FYM } \\
\hline & 100 & 120 & 140 & 100 & 120 & 140 \\
\hline 160 & 274.20 & 363.60 & 453.00 & 231.55 & 309.35 & 387.15 \\
\hline 180 & 252.60 & 342.00 & 431.40 & 212.75 & 290.55 & 368.35 \\
\hline 200 & 231.00 & 330.40 & 405.00 & 193.95 & 271.75 & 349.55 \\
\hline 220 & 209.40 & 298.80 & 388.20 & 175.15 & 252.95 & 330.75 \\
\hline 240 & 187.80 & 277.20 & 366.20 & 156.35 & 234.15 & 311.95 \\
\hline 260 & 166.20 & 255.60 & 345.00 & 137.55 & 215.35 & 293.15 \\
\hline
\end{tabular}

Table 4. Ready reckoners of phosphorus requirement for different yield target of pre-seasonal sugarcane ratoon.

\begin{tabular}{|c|c|c|c|c|c|c|}
\hline \multirow{3}{*}{$\begin{array}{l}\text { Soil available } \\
\text { P }\left(\mathrm{kg} \mathrm{ha}^{-1}\right)\end{array}$} & \multicolumn{6}{|c|}{ Yield target $\left(\mathrm{t} \mathrm{ha}^{-1}\right)$} \\
\hline & \multicolumn{3}{|c|}{ Without FYM } & \multicolumn{3}{|c|}{ With FYM } \\
\hline & 100 & 120 & 140 & 100 & 120 & 140 \\
\hline 6 & 142.08 & 153.38 & 204.48 & 99.04 & 121.44 & 143.84 \\
\hline 12 & 137.44 & 168.64 & 199.84 & 95.72 & 118.12 & 140.52 \\
\hline 18 & 132.80 & 164.00 & 195.20 & 92.40 & 114.80 & 137.20 \\
\hline 24 & 128.16 & 159.36 & 190.56 & 89.08 & 111.48 & 133.88 \\
\hline 30 & 123.52 & 154.72 & 185.92 & 85.76 & 108.16 & 130.56 \\
\hline 36 & 111.88 & 150.08 & 181.28 & 82.44 & 104.84 & 127.24 \\
\hline
\end{tabular}

Table 5. Ready reckoners of potassium requirement for different yield target of preseasonal sugarcane ratoon.

\begin{tabular}{|c|c|c|c|c|c|c|}
\hline \multirow{3}{*}{$\begin{array}{l}\text { Soil available } \\
\mathrm{K}\left(\mathrm{kg} \mathrm{ha}^{-1}\right)\end{array}$} & \multicolumn{6}{|c|}{ Yield target $\left(\mathrm{t} \mathrm{ha}^{-1}\right)$} \\
\hline & \multicolumn{3}{|c|}{ Without FYM } & \multicolumn{3}{|c|}{ With FYM } \\
\hline & 100 & 120 & 140 & 100 & 120 & 140 \\
\hline 250 & 177.00 & 244.40 & 311.80 & 153.20 & 214.40 & 275.60 \\
\hline 300 & 145.00 & 212.40 & 279.80 & 124.20 & 185.40 & 246.60 \\
\hline 350 & 113.00 & 180.40 & 247.80 & 95.20 & 156.40 & 217.60 \\
\hline 400 & 81.00 & 148.40 & 215.80 & 66.20 & 127.40 & 188.60 \\
\hline 450 & 49.00 & 116.40 & 183.80 & 37.20 & 98.40 & 159.60 \\
\hline 500 & 17.00 & 84.40 & 151.80 & 8.20 & 69.40 & 130.60 \\
\hline
\end{tabular}

on Inceptisol, the fertilizer doses required for the average soil test values of the test crop experiment $(200,10$ and $350 \mathrm{~kg} \mathrm{ha}^{-1} \mathrm{~N}, \mathrm{P}$ and $\mathrm{K}$ respectively) were found $330.40,164.00$ and $180.40 \mathrm{~kg} \mathrm{ha}^{-1}$ of $\mathrm{N}, \mathrm{P}_{2} \mathrm{O}_{5}$ and $\mathrm{K}_{2} \mathrm{O}$ respectively. However, in order to produce yield $120 \mathrm{t}$ $\mathrm{ha}^{-1}$ of preseasonal sugarcane ratoon with an average soil test values of the experiment $(200,10$ and $350 \mathrm{~kg}$ $\mathrm{ha}^{-1} \mathrm{~N}, \mathrm{P}$ and $\mathrm{K}$ respectively). The fertilizer requirement would be $271.75,114.80$ and $156.40 \mathrm{~kg} \mathrm{ha}^{-1}$ of $\mathrm{N}, \mathrm{P}_{2} \mathrm{O}_{5}$ and $\mathrm{K}_{2} \mathrm{O}$ respectively. Whereas, producing $140 \mathrm{t} \mathrm{ha}^{-1}$ of preseasonal sugarcane (ratoon), the fertilizer doses required for the average soil test values of the test crop experiment $\left(200,10\right.$ and $350 \mathrm{~kg} \mathrm{ha}^{-1} \mathrm{~N}, \mathrm{P}$ and $\mathrm{K}$ respectively) were found 490.40, 195.20 and 247.80 of $\mathrm{N}, \mathrm{P}_{2} \mathrm{O}_{5}$ and $\mathrm{K}_{2} \mathrm{O}$ respectively. However, in order to produce $140 \mathrm{t} \mathrm{ha}^{-1}$ preseasonal sugarcane (ratoon) with an average soil test values of the experiment $\left(200,10\right.$ and $350 \mathrm{~kg} \mathrm{ha}^{-1} \mathrm{~N}, \mathrm{P}$ and $\mathrm{K}$ respectively). The fertilizer requirement would be $349.55,137.20$ and 217.60 of $\mathrm{N}, \mathrm{P}_{2} \mathrm{O}_{5}$ and $\mathrm{K}_{2} \mathrm{O}$ respectively. Similarly The fertilizer adjustment equations and a ready reckoner of optimum fertilizer doses at varying soil test values for attaining yield target of 40 and $50 \mathrm{q} \mathrm{ha}^{-1}$ of rice yield have been calibrated based on the targeted yield concept (Kanhaiya and Singh, 2014).

Application of residual FYM @ $30 \mathrm{t} \mathrm{ha}^{-1}$ to preseason- al sugarcane (ratoon) along with soil test based fertilizer recommendation would be able to save 58.65, 49.2 and $24 \mathrm{~kg} \mathrm{ha}^{-1} \mathrm{~N}, \mathrm{P}_{2} \mathrm{O}_{5}, \mathrm{~K}_{2} \mathrm{O}$ respectively for $120 \mathrm{tha}^{-1}$ yield target. While in case of 40.85, 58.0 and $30.2 \mathrm{~kg}$ $\mathrm{ha}^{-1} \mathrm{~N}, \mathrm{P}_{2} \mathrm{O}_{5}, \mathrm{~K}_{2} \mathrm{O}$, respectively for $140 \mathrm{t} \mathrm{ha}^{-1}$ yield target. Similar results were also reported by Sakarvadia et al. (2012) and they found yield targeting approach effective for soil fertility build up in medium black calcareous soils on garlic.

\section{Conclusion}

Targeted yield concept was found to be the best for fertilizer requirements of preseasonal sugarcane ratoon for yield targets of 100, 120 and $140 \mathrm{t} \mathrm{ha}^{-1}$. Soil test based balanced fertilizer recommendation under STCR by conjoint use of organic and inorganic fertilizer for preseasonal sugarcane ratoon not only helped in achieving higher yield targets but also in the maintenance and built up of soil fertility.

\section{REFERENCES}

Bangar, A. R. (1991). Quantitative evaluation of efficiency of soil tests and fertiliser responses to sorghum cv. CSH $-8 \mathrm{R}$ through some soil fertility appraisal techniques under varying moisture regimes of dryland Vertisols. $\mathrm{Ph}$ D. Thesis submitted to Mahatma Phule Krishi Vidyapeeth, Rahuri. 
Bhandari, A. L., Ladha, J. K., Pathak, H., Padre, A. T., Dawae, D. and Gupta, R. K..(2002).Yield and soil nutrient changes in a long-term rice-wheat rotation in India, Soil Science Society of America Journal, 58:185-193

Chapman, H. D. and Pratt, P. F.(1961). Methods of analysis for soil, plant and water. Pp. 309. Div. Agril. Sci. California Univ., USA.

Hanway, J. and Heidal, H. D. (1952). Soil analysis method used in Iowa state college soil testing laboratory. Iowa Agriculture, $57: 1-31$

Jackson, ML. (1973). Soil Chemical Analysis. New Delhi : Prentice Hall of India Pvt. Ltd.

Jadhav, MB., Bhalerao, V.P. and Bhoi, P.G. (2002).Targeted Yield trial in suru sugarcane considering amount of organic matter used (Var.Co.86032). Deccan Sugar Technologist Associations, $51^{\text {st }}$ Annual Conventions: A74- 78

Kanhaiya, Lal Regar and Singh, V. (2014). Fertilizer recommendation based on soil testing for the targeted yield of rice in eastern plain zone of Uttar Pradesh. The Bioscan, 9(2): 531-534

Karem, K. S., Puri, G. and Sawarkar, S. D. (2012). Soil test based fertilizer recommendation for targeted yield of rice-wheat cropping sequence and its validation in Vertisol. Journal of Soils and Crops, 22(2):302-308

Katharine, S. P., Santhi, R., Maragatham, S., Natesan, R., Ravikumar, V. and Pradip Dey. (2013). Soil test based fertilizer prescriptions through inductive cum targeted yield model for transgenic Cotton on Inceptisol. IOSR Journal of Agriculture and Veterinary Science, 6(5):3644

Khosa, M. K., Sekhon, B. S., Ravi, M. S., Benipal, D. S. and Benbi, D. K. (2012). Performance of target yield based fertilizer prescription equations in rice-wheat cropping system in Punjab. Indian Journal of Fertilizers, 8(2):1418

Ladha, J. K., Dawe, D., Padre, A. T., Yadav, R. L., Singh, B., Singh, Y., Singh, P., Kundu, A. L. Sakal, R., Ram, N., Regni, A. P., Gami, S. K. Bhandari, A. L., Amin, R., Yadav, C. R., Bhattarai, E. M., Das, S., Aggarwal, H. P., Gupta, R. K. and Hobbs, P. R. (2003) How extensive are yield declines in long-term rice-wheat ex- periments in Asia? Field Crops Research, 81:159-180

Manna, M. C., Swarup, A., Wanjari, R. H., Ravankar, H. N., Mishra, B., Saha, M. N., Singh, Y. V., Sahi, D. K. and Sarap, P.A. (2005). Long-term effect of fertilizer and manure application on soil organic carbon storage, soil quality and yield sustainability under sub-humid and semi-arid tropical India. Field Crops Research, 93: 264 $-280$

Olsen, S. R., Coles, C. V. Watanabe, F. S. and Dean, L. N. (1954). Estimation of available phosphorus in soils by extraction with sodium bicarbonate. USDA Circular 939

Panse, V. G. and Sukhatme, P. V. (1985). Statistical methods for agricultural workers. Indian Council Agricultural Reasearch, New Delhi, Pp. 134-153

Patil, J. P., More, N. B., Ankalkope, M. N. and Jadhav, B. S. (1994). Yield Targeting in seasonal sugarcane (Co.740). Deccan Sugar Technologist Associations, $48^{\text {th }}$ Annual Conventions: A-207-212

Ramamoorthy, B., Narsimhan, R. L. and Dinesh, R. S. (1967). Fertilizer application for specific yield targets of Sonora-64. Indian Farming, 27(4): 43-44

Sakarvadia, H. L., Polara, K. B., Davaria, R. L., Parmar, K. B. and Babariya, N. B. (2012). Soil test based fertilizer recommendation for targeted yields of garlic crop. $A n$ Asian Journal of Soil Science, 7(2):378 382

Santhi, R., Bhaskaran, A. and Natesan, R. (2011). Integrated fertilizer prescriptions for beetroot through inductive cum targeted yield model on an alfisol, Commununications in Soil Science and Plant Analysis, 42: 1905-1912

Santhi, R., Natesan, R. and Selvakumari, G. (2002). Soil test crop response correlation studies under integrated plant nutrition system for onion (Allium cepa L. var. Aggregatum) in Inceptisols of Tamil Nadu. Journal of the Indian Society of Soil Science, 50 (4) : 489-492

Subbiah, B. V. and Asija, G. L. (1956). A rapid procedure for the estimation of available nitrogen in soils. Current Science, 25: 259-260

Vajantha, B., Subbarao, M., Nagamadhuri, K. V., Hemanth Kumar, M. and Sarala, N. V. (2014). STCR approach for optimizing yield, quality and economics in Sugarcane.Current Biotica, 8(3): 309-312 